\title{
A Measure of the Elasticity of Substitution in the Manufacturing Sector of Pakistan*
}

\section{Rukhsana Kalim}

\begin{abstract}
From a technological perspective, the paper is mainly concerned with finding the employment potential in different groups of industries of Pakistan. The role of factor prices in determining techniques of production in the industrial sector through elasticity of substitution has been analysed. Besides taking the large-scale manufacturing sector as a whole, three broad categories of industries viz., consumer goods, intermediate goods and capital goods industries has been selected in particular for the empirical analysis. By utilising the OLS technique, the cross-section analysis for the year 1995-96 has been made. Our results indicate the there is great potential for employment in the intermediate and capital goods industries provided there are no factor price distortions in the economy.
\end{abstract}

\section{Introduction}

Employment generation in different sectors of the economy has been a fervent dream of Pakistan's policy makers. At present, the problem of ensuring productive employment opportunities to an ever growing labour force has emerged as a major challenge to the economy. According to the Pakistan Economic Survey, 2000-2001, the total labour force is 39.4 million, of which 2.4 million remained unemployed in 1998-99. The average rate of open unemployment is 6.1 per cent in 1999-2000 as quoted in the Pakistan Economic Survey, 2000-2001. The figures on open unemployment are underestimated and may not reflect the true picture of the employment problem because of the existence of disguised unemployment in the informal and non-wage sector.

As far as the industrial sector of Pakistan is concerned, it was developed rapidly and showed spectacular growth rates particularly during the 1960s and 1980s. However, its contribution towards employment generation was not very encouraging. For instance, the share of manufacturing in Gross Domestic Product (GDP) escalated from around 14 per cent in 1960 to 17 per cent in 2000. The annual average growth rate of the manufacturing sector was 10 per cent and 6.2 per cent during $1980-85$ and 1997-98 respectively

\footnotetext{
* The article is part of the author's Ph.D. thesis. Some of the data has been updated and minor changes incorporated.

* The writer is Associate Professor of Economics at the University of Lahore.
} 
(Pakistan Economic Survey, 1998-99). Employment in the manufacturing sector declined from 14.7 per cent in 1960 to 11.2 per cent in 2000. It grew at an annual average rate of 1.1 per cent per annum during 1980-85 but remained stagnant in 1997-98. Output and employment figures in the manufacturing sector represent the strong capital intensive bias of this sector.

Earlier, one of the major factors considered responsible for capital intensity was factor price distortions and was taken as a root cause of low employment in the large-scale manufacturing sector of Pakistan (see Hussain, 1974; Kemal, 1981).

Despite government claims of ensuring a free interplay of market forces after the 1980s, the continuity of a host of investment incentives such as tax holidays, low interest rates to domestic as well as foreign investors keep distorting the rental cost of capital. It could be argued that the role of factor prices in determining factor combinations in the production process has not faded in Pakistan. Higher cost of labour relative to cost of capital may induce entrepreneurs to use more capital than labour thus enhancing capital intensity in the sector and affecting employment.

The paper is essentially designed to explore the impact of relative factor prices on industrial employment and to examine the scope and potential of labour absorption in different groups of industries. For such an analysis one needs to estimate the elasticity of substitution between capital and labour in the sector. Positive and high elasticity of substitution indicates the potential of employment in the sector.

Earlier, some attempts have been made to estimate the elasticity of substitution between capital and labour in Pakistan. For instance, Hussain (1974) by using cross section data for the periods 1959-60 to 1970 estimated the elasticity of substitution. The elasticity estimates $(0.76)$ were statistically significant at the 5 per cent level. The weakness of the study is that the statistical analysis was on a highly aggregated basis. Kazi, et al (1976), used the constant elasticity of production function and estimated the production relationship in Pakistan's manufacturing sector at the interindustry level by fitting both cross-section and time-series data. The study recognised the limitations of fitting production functions for time-series data such as multicollinearity, misspecification of adjustment of lags and cyclical conditions. The data was related to only two provinces of Pakistan and may not be an unbiased estimate for the whole of Pakistan.

Kemal (1981) estimated the elasticity of substitution between capital and labour by fitting both the CES and VES production functions to 16 different industries and to the large-scale manufacturing sector as a whole. Time series data was used for the period 1959-60 to 1969-70. The substitution 
elasticities were found to be low in most of the industries. Apart from the customary weakness of time series analysis Kemal (1981) was severely criticised by Ahmed (1982) for using his own adjusted data to allow for under coverage.

Malik et al (1989) used cross-section data for six different years to estimate the elasticity of substitution in the textile industry of Pakistan and found the magnitude of the elasticity to be greater than one. As the study estimates were confined to only one industry no clue can be made about the technological features of other industries.

This paper hopefully contributes to the earlier studies on many accounts. First, no effort has yet been made to take into account the structure of industries in the estimation of the elasticity of substitution. In this study, the elasticity of substitution for consumer, intermediate and capital goods industries is estimated separately. Second, earlier studies are mainly related to the era of the 1960 s that was characterised by the dominance of consumer goods industries using imported machinery at that time. After the 1970s, there was a structural shift towards the development of intermediate and capital goods industries. Employment potential in these groups of industries has not been explored in depth. Third, our data cover the whole manufacturing sector of Pakistan and are not confined to only some of the provinces. In order to avoid difficulties in time-series data, cross-section analysis is made. Subject to the availability of data, the period selected for the analysis is 1995-96.

\section{Model and Assumptions}

Various classes of production functions exist in the economic literature (for details see Walter, 1963, 1968; Hildebrand and Liu, 1965; Nerlove, 1967; and Ferguson, 1969) but for empirical estimates of the elasticity of substitution the most widely used production functions are the Cobb-Douglas (CD), and the Constant Elasticity of Substitution (CES). It is well known that under the assumption of competitive conditions and constant returns to scale the $\mathrm{CD}$ production function invariably results in unitary elasticity of substitution (see Thrilwall, 1983 for mathematical proof). Arrow, Chenery, Minhas and Solow (1961) developed the CES production function in which the elasticity of substitution can take any value from zero to infinity.

To measure the degree of substitution between capital and labour, the more general CES production function introduced by Arrow, Chenery, Minhas and Solow (1961) is used. First, the model is used in its restrictive form where constant returns to scale are assumed. Later, the restriction is relaxed by allowing variable returns to scale. Other assumptions of the model are:

- Firms are profit maximisers. 
- A range of alternative techniques of production is available.

- There is no cost involved in the transfer of technology.

- Firms are on their production frontier.

The above mentioned assumptions are very restrictive and have been criticised by many economists (see Clark, 1985). By assuming two factors of production, capital $(\mathrm{K})$ and labour $(\mathrm{L})$, the CES production function in its general form may be written as:

$$
Y=g\left[d K^{-r}+(1-d) L^{-r}\right]^{-v / r} \quad V=1
$$

Where:

Y represents the total value of output.

$\mathrm{K}$ is the actual inputs of capital services measured in money terms at constant prices.

$\mathrm{L}$ is the actual inputs of labour measured in man-per year.

$\mathrm{g}$ is the efficiency parameter.

$\mathrm{d}$ is the distribution parameter.

$r \quad$ is the substitution parameter.

$\mathbf{v}$ is the degree of homogeneity.

The technology embodied in the production function of the form (1) is depicted in three different parameters i.e. $\mathrm{g}, \mathrm{d}$, and $\mathrm{r}$ and are assumed to be constant. g, "the efficiency parameter" measures the volume of output obtained from given quantities of inputs. $d$ "the distribution parameter" is a measure of capital intensity of the technology and it also indicates the distribution of income between capital and labour. $\mathbf{v}$ is "the degree of homogeneity" of the function. $v$ will be 1 in the case of constant returns to scale, less than 1 for decreasing returns to scale and greater than 1 for increasing returns to scale. The elasticity of substitution (s), is a simple function of $r$, the substitution parameter, and is written as:

$$
\mathrm{s}=\frac{1}{1+\mathrm{r}}
$$

Since the CES production function is highly non-linear, it cannot be estimated directly by Ordinary Least Squares (OLS) unless linearised. There 
are many ways to linearise the function but these require the measurement of the value of capital stock (see Intrilligator, 1978 for details and references) which incorporates both conceptual and empirical problems. This can be avoided by using the indirect estimation procedure suggested by Arrow, Chenery, Minhas and Solow (1961). The indirect estimation of the CES production function however, is very restrictive. It is assumed that perfect competition and profit maximisation conditions prevail and factors receive shares equal to their marginal product. Such conditions also require the assumption of constant returns to scale (see Intriligator, 1978). Hence, V is set equal to 1 in equation 1 . The assumption of perfect competition in both factor and product market is very restrictive and may not be very realistic in the case of Pakistan. However, the element of imperfection in product and factor markets cannot be introduced in our model because of lack of data and thus our results may be biased upwards to some extent.

The mathematical procedure of obtaining the estimation form of the CES production function is based on the marginal productivity of labour relation derived from the equation. The estimated form of the function is:

$$
\log \mathrm{Y} / \mathrm{L}=\mathrm{a}+\mathrm{blog} w+\mathrm{u})
$$

The above indirect specification of the CES production function has been widely used in empirical studies for the estimation of the elasticity of substitution in developing countries. The advantage of this formulation, despite its restrictive assumption is that it does not require capital stock data, the estimation of which involves many problems especially in developing countries.

\section{Relaxation of Assumptions and Returns to Scale}

Equation (2) is very restrictive and assumes constant returns to scale. In the presence of economies of scale, output increases more than proportionately to the increase in inputs and the escalation in labour productivity may also reflect the existence of economies of scale. In this case employment will be reduced by the degree of economies of scale through their effect on labour productivity.

By relaxing the assumptions of constant returns to scale, Brown and Cani (1962) generalised the CES production function by allowing the parameter $\mathrm{v}$ to vary. The less restrictive form of the model, however, violates the principle of marginal productivity theory and the assumption of perfect product and factor market no longer remains valid. The general version of the CES production function takes the following form for estimation purposes:

$$
\log \mathrm{Y} / \mathrm{L}=\mathrm{a}+\mathrm{b} \log \mathrm{w}+\operatorname{cog} \mathrm{V}+\mathrm{u})
$$


Where $\mathrm{a}$ and $\mathrm{b}$ have the same properties as in equation (2) and $\mathrm{V}$ is real value added while c measures the economies of scale and is equal to:

$$
\mathrm{c}=(1-\mathrm{b})(\mathrm{v}-1) / \mathrm{v}
$$

Knowing the value of this expression and the value of $b$ permits the estimation of $v$, the degree of returns to scale in each industry. According to equation (4) for any given value of $\mathrm{v}$ greater than unity (increasing returns to scale), $c$ is a linearly decreasing function of the elasticity of substitution.

Equation 3 relates labour productivity to real wages and output. In this model the coefficient on log wages measures the elasticity of labour displacement by capital due to increase in real wages. Similarly, holding wages constant, any increase in output will increase productivity through returns to scale. Increasing returns to scale at a point of time may reflect the scale and size of firms.

\section{Methodology, Data and Variables}

We estimate the elasticity of substitution between capital and labour for the large-scale manufacturing sector as a whole and then at different group of industries level by using two specifications of the model given below:

$$
\begin{array}{lll}
\log \mathrm{Y} / \mathrm{L}=\mathrm{a}+\mathrm{b} \log \mathrm{w}+\mathrm{u}) & \text { (equation 2) } & \text { Model } 1 \\
\log \mathrm{Y} / \mathrm{L}=\mathrm{a}+\mathrm{b} \log \mathrm{w}+\operatorname{cog} \mathrm{V}+\mathrm{u}) & \text { (equation 3) } & \text { Model } 2
\end{array}
$$

We have fitted the above-mentioned two different specifications of the CES function (equation 2 and 3) to the data on 144 five-digit industries according to the Pakistan Industrial Standard Classification (PISC) and estimated the elasticity of substitution. Later, we have grouped industries into three broad categories according to the end use viz: consumer goods, intermediate goods and capital goods industries and estimated the elasticity of substitution among them.

The cross-section data has been used for the period 1995-96. In the perspective of numerous problems in time-series estimates (see Bhalla, 1975; Wynn and Holden, 1974) we have confined our analysis to the cross-section estimates.

The main source of data is the Census of Manufacturing Industries (CMI), which is the comprehensive and systematic record for the manufacturing sector. Data in Pakistan like other developing countries suffer from many shortcomings, which require caution in deriving any conclusion based on these results. The following are the definitions of the variables used in the study:- 
Value-Added: Value-added is at constant factor cost of 1975-76. It is deflated by the wholesale price index. A true value-added deflator could not be used because of the non-availability of detailed information on intermediate inputs and their prices.

Employment: Employment is measured as the total number of production and non-production workers engaged in each industry. Since the CMI does not provide any information on man-hours, the age/sex composition of the labour force and skills, no adjustments are possible in the employment variable for these factors. Failure to adjust for these factors may bias our estimates of the elasticity of substitution downwards because a high ratio of skilled labour in some industries will be associated with high productivity. Nevertheless, it is generally recognised that a large proportion of the labour force in developing countries is unskilled and Pakistan is no exception to this.

Wage Rate: This is the average wage obtained by dividing total wages (including cash and non cash benefits) by the number of workers. To ensure that real wages reflect employer's cost, these are deflated by the wholesale price index.

Productivity: This is simply the ratio of total value added to total number of workers.

\section{Hypothesis}

We test a number of hypotheses in our estimates. Our null hypothesis is that the elasticity of substitution is equal to zero against the alternative hypothesis that the elasticity is different from zero and substitution possibilities between capital and labour with respect to relative factor prices exist in the large-scale manufacturing sector of Pakistan. It is hypothesised that different groups of industries have specific technological features and reflect different magnitudes of elasticity.

As a rule of thumb in the interpretation of results, we assume in this study that if the magnitude of the elasticity of substitution is equal to or greater than 0.5 and statistically significant, a substantial effect of factor prices on labour productivity and employment will take place, but if it is less than 0.5 , it would indicate the fixed factor proportion and rigid technology.

\section{Results}

We began by running OLS regression using mode1 1 (equation 2) and model 2 (equation 3) and then checking for the presence of heteroscedasticity in our models by applying different tests. The Glejser test 
(see Johnston,1987), where the absolute values of the residuals are regressed on the independent variable to which the variance of the disturbance term is thought to be related confirms the presence of heteroscedasticity in the second model for all industries at the 5 per cent level of significance.

The form, which has been used to correct for heteroscedasticty in the first model is the "dependent variable heteroscedasticty" and has been applied to cross-section studies of household expenditure by Prais and Houthakkar (1955) and Theil (1971). After correcting for heteroscedasticity in the second model (equation 3) the final result rejects its presence at the 5 per cent level.

Our first model (equation 2) gives highly significant results (Table 1). For the whole manufacturing sector, the elasticity of substitution with respect to the wage rate is significantly different from zero at the 1 percent level of significance. The sign of the coefficient coincides with our expectations. The elasticity is about unity which indicates a proportional relationship between real wage rate changes and labour productivity changes. The $R^{2}$ shows that labour productivity changes are also explained by other unmeasured factors, which cannot be considered in this specification of model.

Table-1: Cross-Section Estimates of the Elasticity of Substitution for Pakistan's Manufacturing Sector (1995-96)

Model 1: $\log Y / L=a+b \log w+u)$

\begin{tabular}{lccccc}
\hline \multicolumn{1}{c}{ Source } & a & $\mathbf{b}$ & t-ratio & $\mathbf{R}^{2}$ & $\begin{array}{c}\text { No. of } \\
\text { Observations }\end{array}$ \\
\hline All Industries & 1.46 & 0.96 & $7.79 *$ & 0.23 & 144 \\
Consumer Goods & 5.79 & 0.35 & $2.18^{* *}$ & 0.02 & 66 \\
Intermediate Goods & -2.54 & 1.62 & $724 *$ & 0.60 & 39 \\
Capital Goods & 2.36 & 0.85 & $3.51 *$ & 0.24 & 39 \\
\hline
\end{tabular}

* Significant at the $1 \%$ level. $\quad *$ Significant at the $5 \%$ leve1.

From the structural point of view the elasticity of substitution in consumer goods industries is significant at the 5 per cent level but the overall fit is not good in terms of low $\mathrm{R}^{2}$. The low elasticity of substitution implies that technology in consumer goods industries is not flexible and changes in real wages may not have any significant effect on employment through substitution of capital for labour. Consumer goods industries may not be responding to market signals due to the imperfections in product 
and factor markets. It seems that some other factors may be affecting labour productivity in consumer goods industries than wage increases alone.

Intermediate goods industries however, give highly significant results. The elasticity of substitution is greater than unity (1.62) indicating a very strong effect of real wages on labour productivity. The $R^{2}$ shows that 60 per cent of the changes of the dependent variable are explained by the independent variables (Table 1).

The size of the elasticity of substitution $(0.85)$ in capital goods is close to unity. The effect of changes in real wages on labour productivity is significant and again shows substitutability between capital and labour.

The results of the second specification of the model (equation 3) are shown in Table 2. The fit of the model has improved to a large extent which is shown by the rise in $\mathrm{R}^{2}$ in all cases indicating that the alternative specification of the model has more explanatory power. The results show that both real wage rate changes and output changes affect labour productivity. The magnitude of the elasticity of substitution is low (0.61) in the second model as compared to $(0.96)$ in the first model. As the output variable $(\mathrm{V})$ is included in the second model and a part of the increase in labour productivity is now explained by the changes in output through the scale effect, so the elasticity of substitution parameter has fallen.

Value-added changes have also a significant effect on labour productivity. An increase in value-added of 1 percent, wages being constant will raise labour productivity by 17 percent. The $t$ ratios show that both of these explanatory variables (wages and value added) are significant at the 1 per cent level of significance.

Table-2: Cross-Section Estimates of the elasticity of substitution for Pakistan's Manufacturing Sector (1995-96)

Model 2: $\log \mathrm{Y} / \mathrm{L}=\mathbf{a}+\mathbf{b} \log \mathrm{w}+\operatorname{clog} \mathrm{V}+\mathbf{u})$

\begin{tabular}{lrrlrlr}
\hline \multicolumn{1}{c}{ Source } & a & b & t-ratio & \multicolumn{1}{c}{ C } & t-ratio & $\mathbf{R}^{2}$ \\
\hline All Industries & 4.85 & 0.61 & $3.15^{*}$ & 0.17 & $4.56^{*}$ & 0.44 \\
Consumer Goods & 7.57 & 0.26 & 1.33 & 0.14 & $3.82^{*}$ & 0.24 \\
Intermediate Goods & 1.79 & 0.89 & $3.32^{*}$ & 0.15 & $2.63^{* *}$ & 0.67 \\
Capital Goods & 6.30 & 0.36 & 1.04 & 0.25 & $2.75^{* *}$ & 0.37 \\
\hline
\end{tabular}

* $1 \%$ level of significance. $\quad * * 5 \%$ level of significance

Note: number of observations is the same as shown in Table-1. 
The $\mathrm{R}^{2}$ indicates that 44 per cent of the variation of the dependent variable is explained by the independent variables. To test the overall significance of the model the $\mathrm{F}$ test has been calculated. The value of $\mathrm{F}$ ( 3 $144)=51.58$ is significantly higher than the critical value of $F(3144)=3.91$ at the 99 per cent level of confidence. This leads us to reject decisively the joint hypothesis of no effect from wages and value added on the productivity of labour. On the basis of these results we may tentatively conclude that for the whole manufacturing sector both wages and value-added have a strong effect on employment through changes in labour productivity. However, the coefficient of wages is larger than the coefficient of value added and implies a stronger effect on productivity than does value added.

The estimates of the second model show that the elasticity of substitution in different industries is less than unity (Table 2). The elasticity of substitution is significant in the intermediate goods industries. The insignificant elasticity parameter in consumer and capital goods industries may be reflecting multicollinearity between real wages and value added. The test for multicollinearity however, rejected its presence in the consumer goods industries. We may say that on average the scale effect is dominant in the consumer goods industries and factor prices may not have any effect on labour productivity via substitution of capital for labour. In the capital goods industries the correlation coefficient between real wages and value added is 0.72 , which may have influenced the effect of real wage rate changes on labour productivity. The output-induced effect on labour productivity is significant in all three categories of industries.

\section{Returns to Scale}

As earlier mentioned the coefficient of $\mathrm{V}$ is defined as:

$$
c=\frac{(1-s)(v-1)}{v}
$$

Once the value of $s$ and $c$ are known through the estimation of mode1 2 , one can easily derive the returns to scale $(\mathrm{v})$ parameter.

\section{Table-3: Returns to Scale in Different Groups of Industries}

\begin{tabular}{lc}
\hline \multicolumn{1}{c}{ Industries } & V \\
\hline All Industries & 1.52 \\
Consumer Goods & 1.26 \\
Intermediate Goods & 3.20 \\
Capital Goods & 1.42 \\
\hline
\end{tabular}


Our estimates of returns to scale show that the manufacturing sector of Pakistan has increasing returns to scale. All three groups of industries show the presence of increasing returns to scale. The industries may have internal and external economies of scale. We think that the increasing returns to scale in the manufacturing sector of Pakistan may not be reflecting the true scale effect. The more plausible reason may be the existence of underutilised capacity. As Guade (1975) pointed out, the existence of idle capacity tends to give results of increasing returns to scale in cross-section estimates. In this context any increase in output is obtained by utilising the existing capacity.

\section{Conclusion and Policy Implications}

Our statistical analysis is limited by a number of factors related to the theory and estimation problems of the production function. Certain problems related to data also place a limitation on the analysis. Hence the results necessitate qualification.

Our statistical results show that two factors, the wage rate and value added play an important role in determining techniques of production. Employment potential exists in the manufacturing sector. Different groups of industries, particularly intermediate and capital goods industries, show a great potential in increasing output and employment through changing factor prices. The magnitude of the elasticity is less than unity in all industry estimates but inter-industry variations do exist. The elasticity magnitude is very high in intermediate and capital goods industries which shows high flexibility in these categories of industries with respect to relative factor prices.

These statistical results help in giving a crude idea about the features of the ruling technology and employment potential in the manufacturing sector of Pakistan. From our final results (Mode1 2) we may reject the null hypothesis that factor prices do not play an important role in determining the choice of techniques. In the light of our analyses we may suggest that if the government of Pakistan continues to distort the capital price by providing a host of incentives to investors, it will further hamper employment opportunities in the manufacturing sector. Similarly, by maintaining a check on the rise in real wages one could expect a higher level of employment in the manufacturing sector of Pakistan. Intermediate and capital goods industries are more prone to such policy measures. The presence of increasing returns to scale in all industrial groups may reflect the existence of idle stock of capital. If it is the case then utilising the idle stock of capital in the industrial sector will not only increase output but also employment in the sector. 
54 The Lahore Journal of Economics, Vol.6, No.2

\section{References}

Ahmed, M., 1982, Substitution Elasticities in the Large-Scale Manufacturing Industries of Pakistan: A Comment. Pakistan Development Review, Vol. XX1, No. 1, Spring, pp. 73-81.

Arrow, K. J., H.B. Chenery, B.S. Minhas and Solow, 1961, Capital Labour Substitution and Economic Efficiency, Review of Economics and Statistics, Vol. 43, No. 1, pp. 155-73.

Bhalla, A. S.(ed)., 1975, Technology and Employment in Industry: A Case Study Approach, ILO, Geneva.

Brown, M. and J.D. Cani, 1962, Technological and Distribution of Income, International Economic Review, Vo1. 36, pp. 39-53.

Clark, N., 1985, The Political Economy of Science and Technology, Basil Blackwe11 Ltd., Oxford.

Diwan, R.K., and D.N. Gujararti, 1968, Employment and Productivity in Indian Industries: Some Questions of Theory and Policy, Artha Vijnam (Pouna), Vo1. 10, No. 1, pp. 29-67.

Federal Bureau of Statistics, 1988, Census of Manufacturing Industries, 1984-85, Karachi.

Ferguson, C.E., 1969, The Neoclassical Theory of Production and Distribution, Cambridge University Press.

Guade, J.S., 1975, Capital Labour Substitution Possibilities: A Review of Empirical Evidence, in Bhalla A.S. (ed). Technology and Employment in Industry: A Case Study Approach, ILO, Geneva.

Guisinger, S. E. and S. Kazi, 1978, The Rental Cost of Capital for the Manufacturing Sector 1959-1960 to 1970-71, Pakistan Development Review, Vol. XV11, No. 4, pp. 385-407.

Federal Bureau of Statistics, 2000, Census of Manufacturing Industries, 1995-96, Karachi.

Ferguson, C. E., 1969, The Neoclassical Theory of Production and Distribution, Cambridge University Press, London. 
Finance Division, Government of Pakistan, 1998, Economic Survey 19981999, Government of Pakistan, Islamabad.

Finance Division, Government of Pakistan, 2001, Economic Survey 20002001, Government of Pakistan, Islamabad.

Finance Division, Government of Pakistan, 2001, Economic Survey 19992001, Government of Pakistan, Islamabad.

Guade, J. S., 1975, Capital-Labour Substitution Possibilities: A Review of Empirical Evidence, in Bhalla, A. S. (ed) Technology and Employment in Industry: A Case Study Approach, ILO, Geneva.

Hildebrand, G.H. and T.C. Liu, 1965, Manufacturing Production Functions in the United States, Ithaca, New York State School of Industrial Labour Relations.

Hussain, I., 1974, Employment Aspect of Industrial Growth in Pakistan, Pakistan Development Review, Vo1. 13, No. 5, pp. 211-221.

Intriligator, M. D., 1978, Econometric Models, Techniques, and Applications, North Holland Publishing Company, Oxford.

Johnston, J., 1987, Econometric Methods, McGraw Hill, International Editions.

Kazi, S., S. Z. Khan, and S.A. Khan, 1976, Production Relationships in Pakistan's Manufacturing Industries, Pakistan Development Review, Vol. XV N. 1, pp. 28-63.

Kema1, A. R., 1981, Substitution Elasticities in the Large-Scale Manufacturing Industries of Pakistan, Pakistan Development Review, Vol. XX, No. 1, Spring, pp. 1-35.

Malik, S., M. Mushtaq, and H. Nazli, 1989, An Analysis of Production Relations in the Large-Scale Textile Manufacturing Sector of Pakistan, Pakistan Development Review, Vol. 28, No. 1, pp. 27-42.

Nerlove, M., 1967, Recent Empirical Studies of the CES and Related Production Functions, in Brown (ed) The Theory and Empirical Analysis of Production, National Bureau of Economic Research, New York, Columbia University Press. 
56 The Lahore Journal of Economics, Vol.6, No.2

Prais, S. J., and H. S. Houthakkar, 1955, The Analysis of Family Budgets, Cambridge University Press, New York.

Theil, H., 1971, Principles of Econometrics, New York, John Wiley and Sons.

Walters, A. A., 1963, Production and Cost Functions: An Econometric Survey, Econometrica, Vo1. 31, pp. 1-66.

Wynn, R. F. and K. Holden, 1974, An Introduction to Applied Econometric Analysis, The Macmillan Press Ltd. 